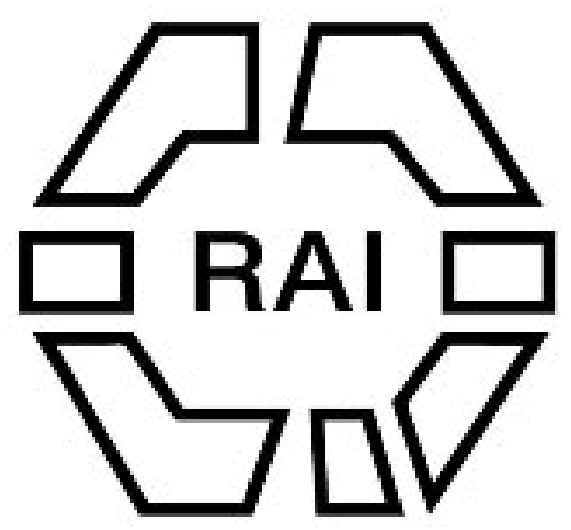

Note on the Preparation and Use of the Kenyah Dart-Poison Ipoh

Author(s): C. G. Seligmann

Source: The Tournal of the Anthropological Institute of Great Britain and Ireland, Vol. 32 (Jan. - Jun., 1902), pp. 239-244

Published by: Royal Anthropological Institute of Great Britain and Ireland

Stable URL: http://www.jstor.org/stable/2842915

Accessed: $15 / 06 / 201404: 21$

Your use of the JSTOR archive indicates your acceptance of the Terms \& Conditions of Use, available at http://www.jstor.org/page/info/about/policies/terms.jsp

JSTOR is a not-for-profit service that helps scholars, researchers, and students discover, use, and build upon a wide range of content in a trusted digital archive. We use information technology and tools to increase productivity and facilitate new forms of scholarship. For more information about JSTOR, please contact support@jstor.org. 


\title{
NOTE ON THE PREPARATION AND USE OF THE KENYAH DART-POISON IPOH.
}

\author{
By C. G. Seligmann, M.B.
}

[With Plates XVI, XVII.]

DuRING the visit of the Cambridge Anthropological Expedition to Sarawak as the guests of Dr. Charles Hose, the opportunity arose of studying the vegetable poison used by natives of the Baram district to poison their blowpipe darts. The physiological effects will be described elsewhere, these notes being limited to the preparation and use of the poison, and only such mention of its chemical nature or physiological effects will be made as may be necessary in order to compare the specimens of poison examined with those obtained by others from Borneo or the Malay Peninsula. Samples of the dart-poison ipoh were obtained from Kenyahs of the Baram district and from a number of immigrant Iban ${ }^{1}$ who have recently taken to the use of the blowpipe and poisoned darts. The last named folk do not usually make the poison themselves but obtain it from the tribes of the interior, such as the Kenyahs.

The term ipoh is used by all up-country natives as a generic name for dartpoison, and is widespread throughout Malaysia, in different parts of which it is applied-often with a qualifying adjective-to the species of Strychnos and Antiaris, from the juice of which the local dart-poison is made. ${ }^{2}$ Among the Kenyahs of the Baram district its use is however strictly confined to the upas tree, Antiaris toxicaria, and to the poison made by inspissating its juice, the active principle of which is a nitrogen-free glucoside which acts on the heart muscle and the central nervous system. As far as can be ascertained, the only sample of dart-poison from

1 This term has been recently suggested by Haddon as a name for the people usually called Sea Dayaks. C'f. A. C. Haddon, Headhunters, Black, White and Brown, 1901, p. 325, and "A Sketch of the Ethnography of Sarawak," Archiv. per l'Anthrop. el'Etnol., xxxi, 1901, p. 341.

2 Various authors have at different times described the addition of white arsenic, realgar and antimony to the dart-poisons prepared in the Malay Peuinsula and even in Borneo. As far as I know, no sample which has been analysed has ever been found to contain any of these. Throughout the Malay Peninsula, arsenic is stated to be largely used in producing the very characteristic watering of kris blades, and here it would be accessible to the non-Malay tribes and likely enough to be mixed with the poison. In Borneo, however, the case is different. During some months spent in the Baram district of Sarawak among a non-Malay people, during which time constant inquiries were made as to the composition and use of dart and other poisons, no mention of arsenic was ever made, nor, as far as could be ascertained, did the Chinese-in whose hands the local trade lies-import it. Again, Ling Roth, in his monumental compilation, has only been able to collect three instances of poisoning which could certainly or probably be traced to arsenic. 
the Baram district hitherto examined was one brought back by Dr. Willy Kükenthal. This had been made by Kayans, and according to Kïkenthal's opinion, based on chemical and physiological grounds, was certainly not the inspissated juice of a toxicaria, nor did it contain a glucoside, "but was to all appearances a quite unknown dart-poison." Only a small amount of the substance was, however, at his disposal and that of Professor Knorr, who examined the chemical composition of the substance, while its action on frogs was so like that of some of the samples of undoubted Antiaris poison I have examined, that I am unable to accept Kiikenthal's views.

Besides its use as a dart-poison, ipoh is administered internally as a medicine. Among the Punans it is commonly given in malaria, more rarely in dysentery. According to Hose, a piece about the size of a pin's head is given twice a day, usually in a banana. Probably this treatment is not continued for more than a short time, since in guinea-pigs three small doses given on alternate days produced death. Hose has seen among the Sebops a foul ulcer treated by pencilling the raw surface with a poisoned dart, and there was no reason to suppose that a dart of less than usual virulence was used. Again, the same authority has seen a man treated with ipoh recover from the bite of a really dangerous snake, Lachesis Wagleri. The treatment consisted of making repeated stabs round the wound, which was then well sucked and finally pencilled with a dart. It was stated that the dart must never be thrust into the wound nor must the treatment be delayed. ${ }^{9}$

As regards the treatment of wounds poisoned by ipoh, they should be immediately excised, after which blachan, a paste made of dried crustacea, should, if possible, be plastered on the wound. The latter practice is not due to any special property of blachan, but, according to Hose, to the native belief that all strongly smelling substances are antagonistic to ipoh. ${ }^{3}$ Experimentally, powdered ipoh mixed with blachan and left for twenty-four hours underwent no diminution in virulence.

1 W. Kükenthal, Ergebnisse einer zoologischen Forschungsreise in den Molukken und Borneo, pp. 284 et seq.

${ }^{2}$ Rumphius, who from 1654 to 1659 collected the material for the Herbarium Amboinense, had heard of the alleged medicinal value of the juice of A.toxicaria. In his great work its leaves are figured as those of the "Macassar poison-tree." Of its inspissated juice his posthumous editor says (vol. ii, p. 269): "Ipo itaque crudum nec commixtum antidotum est contra ictus venatorium piscium, ac morsus millepedarum, si hujus emplastrum vulneri applicetur, quod dọlorem citius sedat, ac venenum melius extrabit quam ullum aliud remedium. Porro si alicujus corpus ulcerationibus et scabie scateat, talis hujus Ipo pilulam cum Musae fructus carne commixtam assumat, quem omnem intestinorum impuritaten attrahet atque expellet."

3 Apparently the same idea existed in Macassar in Rumphius' time. In Herbarium Amboinense (vol. ii, p. 270) it is stated that "Arbor Poele tantum cum hoc veneno exercet odium et antipatiam ut, si ejus ramulus vel folium huic supponatur, vel in camera suspendatur, in qua hoc venenum asservatur, illud ita enervet, ut viribus penitus destitutum fit." Poele is, according to Geiger, a species of Alstonia, many members of which genus are odoriferous. 
The process of collecting the upas sap and its inspissation and subsequent application to the sharpened strips of nibong (Onchosperma horrida) wood to be used as darts, was seen during a stay made at the house of the Murik (Kenyah) chief Taman Aping Koleh at Long Tamala on the Baram river. No magic was used, nor were any charms or incantations muttered at any stage of the proceedings, the whole matter indeed appeared an essentially commonplace and utilitarian affair to Taman Aping Koleh and his people.

A group of upas trees was known to exist a few miles up-stream, close to which was a clump of bamboos. Lengths of these reaching from just below one transverse septum to just below the next were then cut, and the upper open end. pared obliquely to a somewhat blunt point. The upas tree was then scored to the depth of about a quarter of an inch by means of a special form of gouge (Pl. XVII, 6 ), the channels so formed running obliquely and converging to a vertical channel, against the bottom ' of which was placed the pared lip of the bamboo collecting tube (Pl. XVI, 1). The juice so obtained was yellowish-white in colour and of an intensely bitter taste, rapidly becoming buff-coloured on exposure and slightly sticky. Tested with litmus paper a few hours after it had been collected its reaction was neutral.

In the ordinary way the juice soon turns a brownish black and is said to lose its deadly properties, but a sample collected in a tightly corked vessel retained its colour and its strength for months.

The juice was brought to the long-house in the bamboo tubes in which it had been collected, and a number of small open palm-leaf vessels prepared by folding on itself an oblong piece of the leaf of a palm (daun tsang), much as children make paper boxes. The edges at the two ends were not, however, turned over, but the vessel was kept from collapsing and stiffened by short pieces of the mid-rib of the leaflets of a palm (lemojan) run through its walls. Into these vessels, called tabaiyok (Pl. XVII, 7), which were suspended a few feet above one of the open fireplaces of which there are many about the common verandah of the long-house, the juice was poured forming a layer at the bottom about an inch thick. A small fire was kept going under the vessels and the juice stirred from time to time. When it had become a thick viscid mass the vessel was taken down and allowed to cool, when the inspissated juice set to a hard brittle mass. Often before this had taken place and while the mass was still soft enough to take the imprint of the finger, the strips of mid-rib stiffening the vessel were removed and the fast hardening poison rolled up in the leaf, to which it stuck fairly firmly, the ends of the packet so formed being subsequently tied down with a strip of rattan or cord (Pl. XVII, 9).

In this condition it appears to keep indefinitely, and samples which have lain for over two years in an ordinary tim box have in no degree lost their potency.

Among the Kenyahs it appears that the dried juice of A.toxicaria is alone used as a dart-poison; certain other tribes however profess to add other substances with the idea of making their poison more virulent. Dr. Hose informs me that the Milanaus are said to add snake venom, while I obtained from Datu, an Iban,

Vor. XXXXII, 
a specimen of ipoh supposed to contain the pounded fangs of a venomous snake called Ular blalang; microscopical examination failed, however, to yield any evidence in support of this statement, nor did the physiological action of the poison differ in any way from that of other specimens examined. The Punans of the Silat were said on good authority to mix cortical shavings of the wild gambier tree with their fresh ipoh juice; these were strained out before the poison was inspissated. Another specimen given me by Datu, was said to consist of the dried juices of two trees, one of which was the same as the Kenyah ipoh, while the other, a shrub, might from his descriptions have been considered to be a species of Strychnos. Chemical examination however failed to reveal the presence of strychnine, while physiologically the action of this specimen differed in no way from that of other samples of ipoh.

The darts langan are made of strips of palm wood 20-30 cm. long sharpened at one end, rounded and whittled down till their diameter is about $3 \mathrm{~mm}$. (Pl. XVII, 8): Some of the poison is then powdered and mixed with water on a wooden palette or shallow dish (Pl. XVII, 5) to the consistency of a thin paste. This is then smeared on and round the points of the darts for a distance of about $2 \mathrm{~cm}$. Such darts are used for the smaller animals, for big game the point of the dart is split, a thin triangular blade of metal inserted, and the whole plastered with ipoh; $800 \mathrm{mgs}$. of the poison were scraped off one dart of this type. The process takes place before one of the open fireplaces before referred to; the poisoned darts are next arranged on the wooden board forming one wall of the fireplace so that their points projecting toward the fire, which is purposely kept low, receive enough heat to soon dry the poison. The process is well seen in Pl. XVI, 3, where resting on the palette is an old broken dart used for smearing poison on those in the process of manufacture. Beyond this is a bone-handled knife used for powdering the poison, while opposite the right leg of the operator the newly smeared darts are drying one above the other, being laid obliquely across each other from right to left and left to right alternately, their points kept apart by a splinter of wood, often an unpoisoned dart, struck vertically into the beak forming the side of the fireplace.

The butt of the darts, usually adjusted shortly before use, consists of a cone $2-3 \mathrm{~cm}$. long made of the soft pith of the sago palm. The cone itself is truncated, and a number of such cones are usually kept in the quiver below threaded on an unpoisoned dart. The cones are prepared by cutting a number of cylindrical pieces of pith of the right length. These are then roughly pared and placed upon the pointed end of a wooden tool pachon (Pl. XVII, 8) used to ensure the base of the cone accurately fitting the blowpipe. The pachon consists of a rounded handle of hard wood usually more or less ornamented, which at one end is of the same diameter as the bore of its owner's blowpipe; from the centre of this end there projects a rounded spindle some $2 \mathrm{~cm}$. long of about the same diameter as the unpointed end of a dart. The pith cone is forced home on the spindle and its circumference at its base carefully pared to that of the rounded end of the pachon from which the spindle projects, thus ensuring the butt accurately fitting the blowpipe. 
When ready for use the darts are kept points downward in a bamboo quiver the handle of which (Pl. XVII, 3) is tucked into the loin-cloth of the operator. To guard their points a small open bag of the skin of some animal with the fur inside is usually placed mouth upwards in the quiver. Many of the quivers seen also contained a small mass of dried blood which had as its nucleus short fragments of old darts, and in which there were generally imbedded a few teeth and fragments of bones. This conglomeration, called sirop (a generic term for charms), always contained the blood of more than one animal, and when possible the blood of many animals entered into its composition. When hunting it might be smeared with the blood of recently killed animals, but this was by no means invariably done. There seems little doubt that this form of siap worked by, and was a frank example of imitative magic, a conclusion strengthened by the presence in some quivers of small hook-shaped pieces of woud resembling on a smill scale those larger hooks (kawit) which are hung up with skulls in the verandahs of the houses, "with the idea that they will help the head-hunters to obtain more skulls on their forays."

Several blowpipes, klepōt, were seen in the process of manufacture; all these were made from a fairly tough yellow wood. Pieces of this, from 7 to 8 feet long, and some 2 or 3 inches square in cross section, had been seasoning in the verandah for some weeks. When one of these was considered ready, a board was removed from the floor of the pile house, the piece of wood passed through the hole thus formed, and its lower end securely lashed to a base formed by a light scaffolding built among the piles supporting the house (Pl. XVI, 2). The boring (Fig. 1) is done with a rounded iron rod flattened and sharpened at one end. Ling Roth, quoting Crocker, says that the boring iron is chisel pointed. That used by Taman Aping Koleh's people had no flat surface at its cutting edge, the latter being formed at the expense of both surfaces as in a graver's tool. Its blunt end was hafted into a long wooden handle. When the boring was commenced an assistant steadied the edge on the projecting end of the future blowpipe. At first only a rotary movement was imparted to the rod, later when a few inches had been drilled out an up and down motion was given to the borer, which was worked so quickly - for the most part without

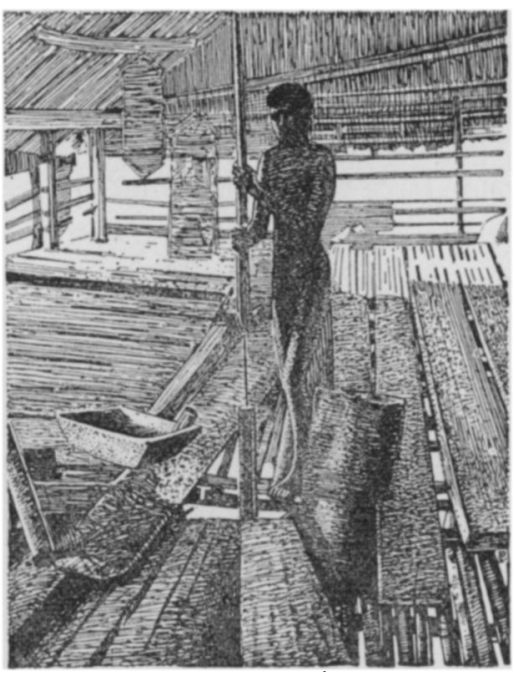

FIG. 1. - KENYAH BORING BLOWPIPE. an assistant-that the rotary movement ceased to be obvious. Throughout the process, which, in expert hands, takes no longer than a day, the drill is constantly wetted. Crocker saw a Rakatan standing

A. C. Haddon, loc. cit., p. 396. 
beneath the piece of wood he was working on and boring upwards. When the boring is finished the superfluous wood is whittled away, and the outside rounded and polished. I did not hear of rattan, as stated by Crocker, or any other material being worked through the finished blowpipe to give the interior of the latter its usual smoothness, but unluckily no special question on this point was put. Finally most of the Murik blowpipes have a spear-head fitted to them; no sights, such as have often been mentioned, were noticed. The iron rod used as a drill, which was stated to have been in the tribe for a long time, was somewhat doubtfully suggested to have been originally obtained from the Chinese.

Prizes offered for the best blowpipe shooting were productive of twelve entries. A rectangular target with a centre of $3 \frac{3}{4}$ inches, an inner of 10 inches and an outer of $16 \frac{1}{2} \times 20 \frac{1}{2}$ inches, was used. At 20 yards out of three shots the two winners each scored two bulls, and only one competitor failed to hit the target. At 30 yards there was a great falling off, at 35 yards all except Lidam the winner shot wildly and for the most part missed the very generous target at least twice out of the three shots allowed. The force with which the darts struck was remarkable, they penetrated the moderately hard wood of the target about $\frac{1}{3}$ of an inch.

In conclusion I take the opportunity of acknowledging my indebtedness to Dr. Charles Hose, Resident of the Baram district of Sarawak, for many specimens of the poison as well as for his invaluable assistance in collecting details from the natives and verifying them for publication in this note. 


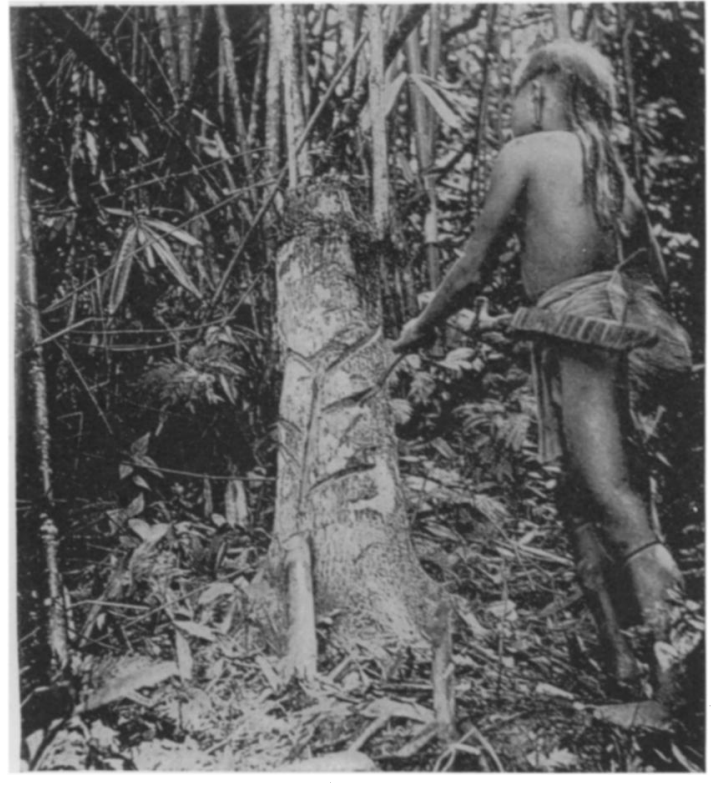

1. SCORING UPAS TREE; THE JUICE COLLECTS IN THE BAMBOO PLACED BELOW VERTICAL CHANNEL.

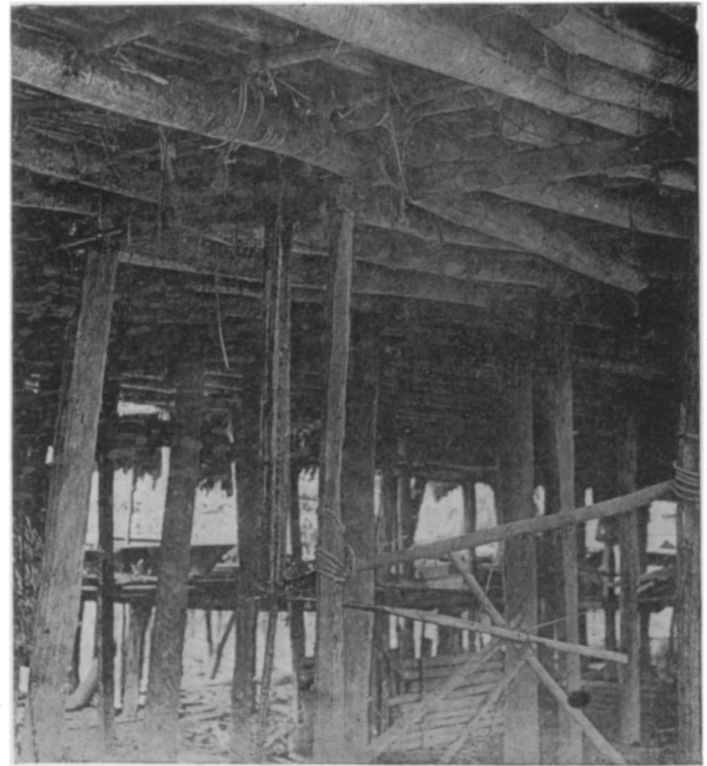

2. BLOWPIPE PROJECTING THROUGH THE FLOOI OF THE HOUSE AND SUPPORTED ON TEMPORARY SCAFFOLDING WHILE BEING BOLED.

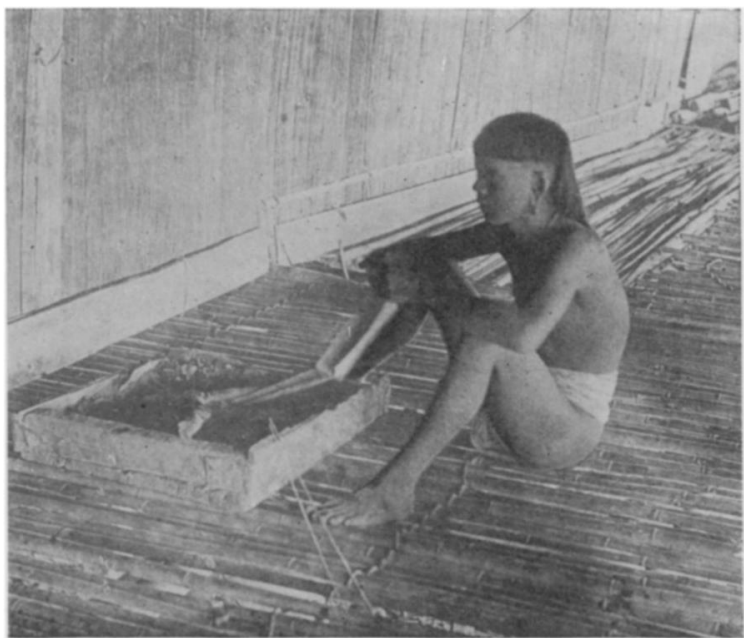

4. MAKING PALM-LEAF VESSEL FOR INSPISSATING THE UPAS JUICE.

THE KENYAH DART-POISON IPOH. 


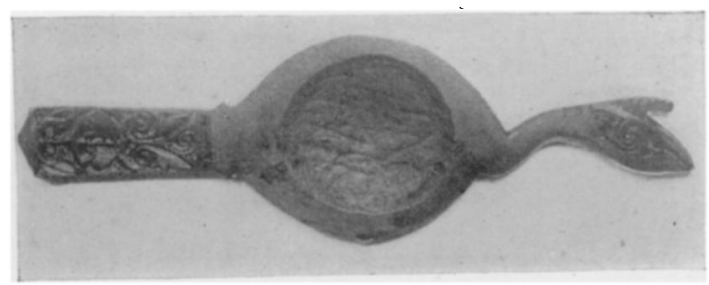

5. WOODEN PALETTE FOR MIXING POISON.

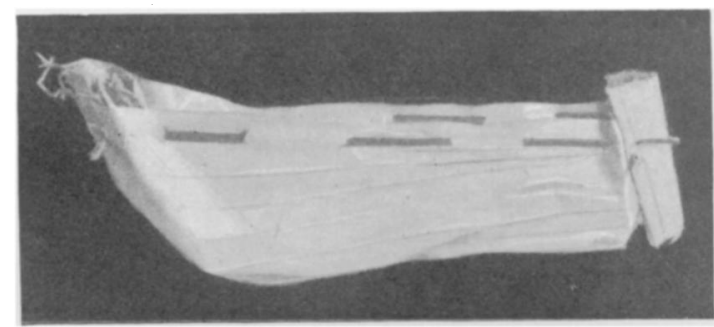

7. TABAIYOK : PALM-LEAF VESSEL FOR HOLDING THE JUICE OF THE UPAS TREE.

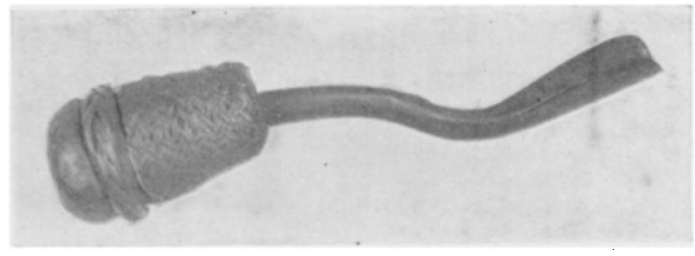

6. GOUGE FOR SCORING THE UPAS TREE.

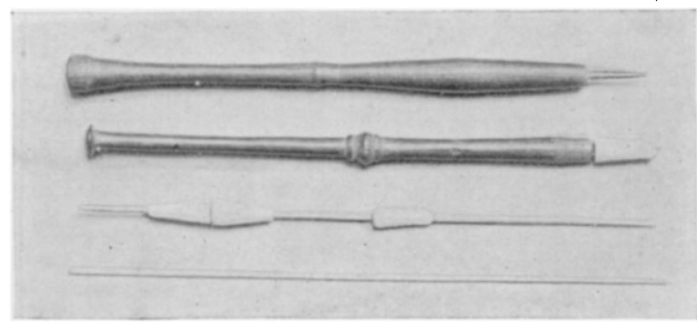

8. PACHON, PACHON WITH PITH BUTT IN POSITION, PITH BUTTS ON DART, AND DART.

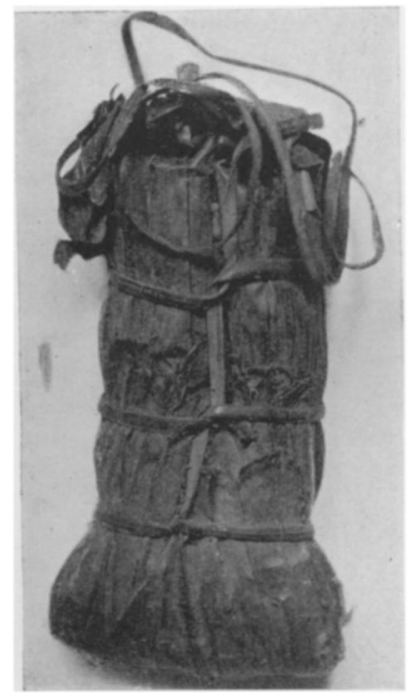

9. FINISHED POISON WRAPPED IN PALM-LEAF.

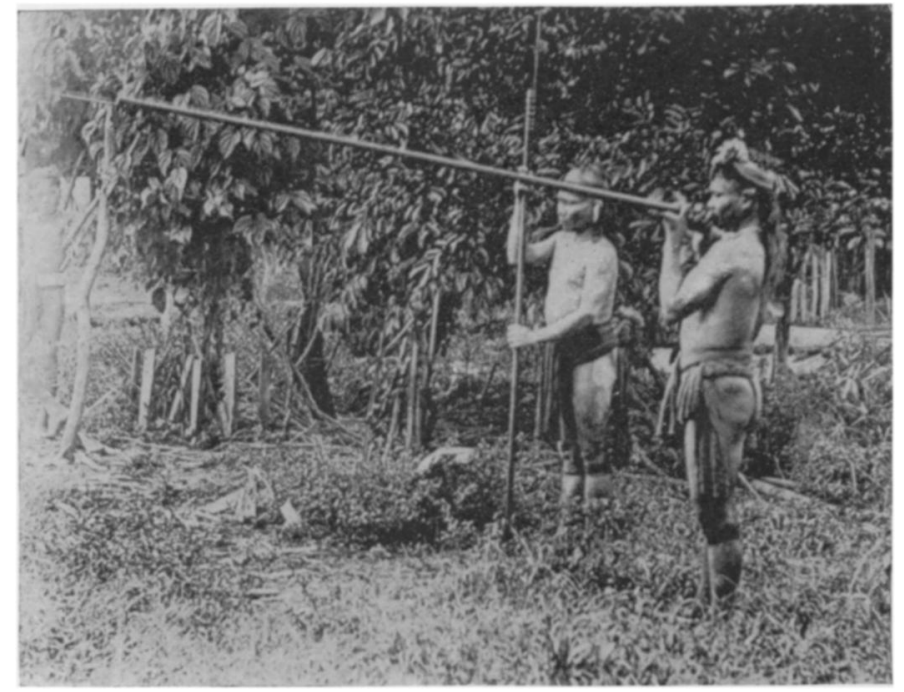

10. KENYAH SHOOTING WI'H BLOWPIPE.

THE KENYAH DART-POISON IPOH. 